\title{
Travessias, antropofagias e hibridismos: novas tessituras literárias
}

\author{
Neiva Kampff Garcia ${ }^{1}$
}

\begin{abstract}
Literature is a space for exchange of experiences of the subjects, embracing their similarities and their differences. Literature reflects the most important issues at the time it is produced, and participates of the evolution and transformation of this time, in a continue exercise of cultural mediation. The Mozambican Mia Couto is a contemporary writer, whose work engages with the past, thinks the present and questions the future of man and its context. He appropriates of the inherited Portuguese language and, with it, crosses the borders of the rules, of the meanings and of the social roles. Breaking with tradition and with the real intellectual patterns, he gives voice to the other and renews the literary word. We realize the work of creation, recreation and resignification prepared by the author as a new literary tessitura, which is based as crossing, anthropophagy and hybridism. While transiting among the historic space of the Portuguese colonialism, of the independence of its country and the formulations of post-colonialism, Mia Couto transposes the discursive limits of the literary production of these periods and establishes wide and innovative cultural mobilities in his texts.
\end{abstract}

Keywords: Mia Couto, Mozambican literature, postcolonialism.

Resumo: A literatura é um espaço de troca de vivências dos sujeitos, abarcando suas semelhanças e suas diferenças. Ela reflete as questões mais importantes do tempo em que é produzida e participa da evolução e transformação desse tempo, num contínuo exercício de mediação cultural. O moçambicano Mia Couto é um escritor contemporâneo, cuja obra dialoga com o passado, pensa o presente e questiona o futuro do homem e do seu contexto. Ele se apropria da língua portuguesa herdada e, com ela, atravessa as margens das regras, dos significados e dos papéis sociais. Ao romper com as tradições e com as normas intelectuais vigentes, ele dá voz ao outro e renova a palavra literária. Entendemos o trabalho de criação, recriação e ressignificação elaborado pelo autor como uma nova tessitura literária, que se fundamenta nos sentidos de travessia, antropofagia e hibridismo. Ao transitar entre o espaço histórico do colonialismo português, da independência de seu país e das formulações inerentes ao pós-colonialismo, Mia Couto transpõe os 
limites discursivos da produção literária desses períodos e instaura amplas e inovadoras mobilidades culturais no seu texto.

Palavras-chave: Mia Couto, literatura moçambicana, pós-colonialismo.

E é isso que um escritor é - um viajante de identidades, um contrabandista de almas. Não há escritor que não partilhe dessa condição: uma criatura de fronteira, alguém que vive junto à janela, essa janela que se abre para os territórios da interioridade. ${ }^{2}$

A literatura contemporânea referenda conceitos como escrita híbrida, de fronteira, da margem e tantos outros, que buscam explicar os sentidos presentes no universo interior do homem atual, de identidade instável e/ou multifacetada. Adentramos ao século XXI falando novas linguagens sociais, políticas, econômicas e, fundamentalmente, culturais. Nessa conjuntura, postulamos que a literatura é um canal de comunicação dessas novas linguagens, possível através de novos "fazeres", e que isso é identificável nos processos de formação das literaturas mais recentes, como no caso moçambicano.

As diferenças cronológicas existentes nos movimentos de independência das nações africanas de colonização portuguesa deram lugar a processos diversos de nacionalismos, mas que agregaram - de modo semelhante - elementos identitários como território, língua e legado histórico-cultural. Os dois primeiros foram influenciados pelo colonizador e o último funcionou como um espaço para o relato da ancestralidade. É desse contexto que surgem os textos escritos que originaram a literatura pós-colonial na África. Nesse sentido, seguimos Ana Mafalda Leite quando afirma que:

Estudar uma literatura africana, implica assinalar a deformação dos modelos ocidentais no processo de apropriação pelos africanos, em processos que vão de "cópia" (século XIX), à ruptura e carnavalização (Bakhtin), mas, também, incorporar esses processos de diálogo com as diferentes culturas indígenas, que continuaram a ser produzidas nas línguas nacionais, bem como as suas formas transmitidas oralmente. (LEITE, 2003:37. Grifo da autora.

A influência do empreendimento colonial sobre o surgimento e a afirmação de escritores africanos - representantes dessas nações - foi decisiva, quer na vigência da dominação ou nos movimentos de independência e pós-independência, promovendo uma espécie de combinação entre a tradição pré-existente e a ruptura com as normas das construções intelectuais eurocêntricas, ou, conforme referiu Laura Cavalcante Padilha, as "nomeações do "centro""3. A retomada da oralidade e a canibalização da língua do invasor, aliadas ao reconhecimento dos múltiplos dialetos étnicos, presentes nos diferentes processos de formação nacional, oportunizaram aos letrados (que dominavam o idioma luso) organizar novas roupagens nas formas escritas. É o que designamos como formas híbridas.

2 Palavras de Mia Couto na conferência de abertura da cerimônia de entrega do "Prémio Internacional dos 12 Melhores Romances de África”, realizada em Cape Town, África do Sul, em julho de 2002. O texto encontra-se publicado, na íntegra, sob o título “Que África escreve o escritor africano?”, em COUTO, Mia. Pensatempos. Textos de opinião. 2. ed. Lisboa: Caminho, 2005, p. 59-63.

3 A expressão foi utilizada na conferência de abertura do I Seminário Nacional "Quando foi o Pós-Colonial? Diálogos, perspectivas e limiares nas literaturas luso-africanas", realizado na UFRGS, em Porto Alegre, em 27 de junho de 2012. 
De cada processo de conquista da independência resultam discursos literários próprios, derivados do modo como tais processos se efetivam. Alia-se a isso a influência que as diferentes manifestações pregressas exerceram sobre as novas textualidades em formação. As similitudes e as diversidades precisam ser cuidadosamente consideradas em qualquer leitura a ser feita, porque, conforme preconiza Ana Mafalda Leite (2003:35), as literaturas africanas emergem em movimentos simultâneos de "(in)definição, partilha e ruptura". Acompanhamos a autora quando diz que:

A textualidade pós-colonial é necessariamente um fenómeno hibridizado, ou plural, no sentido de coexistência de uma pluralidade de formas e de propostas, resultantes da relação entre os sistemas culturais europeus enxertados e as ontologias indígenas, com o seu impulso de criar ou recriar identidades locais, novos campos literários.

Não é possível regressar a uma pureza pré-colonial absoluta, tal como não é possível criar formações nacionais, totalmente independentes das suas implicações históricas na empresa colonial. (LEITE, 2003:36)

A ideia de que a África é um continente homogêneo acompanhou por muito tempo considerações políticas e intelectuais, acreditando na existência de similitudes, tanto pelo viés das manifestações culturais dos povos autóctones, quanto pela condição de um imenso território explorável, economicamente, pelo domínio europeu. A partilha do território continental foi baseada nos interesses e na capacidade de colonização das nações europeias e derivou em rupturas culturais e pertencimentos desencontrados. As relações entre línguas, etnias, religiões e atividades econômicas de sustentação foram desconsideradas pelo empreendimento colonial, gerando situações de choque e/ou entrecruzamentos culturais das comunidades nativas. A premissa do todo foi desconstruída, fragmentada em partes desiguais, implicando, portanto, numa impossibilidade da existência de uma só cultura, de uma macro sociedade africana. É a essa dinâmica que Mia Couto (2005) denomina de "complexas mestiçagens":

África não pode reduzida a uma entidade simples, fácil de entender. O nosso continente é feito de profunda diversidade e de complexas mestiçagens. Longas e irreversíveis misturas de culturas moldaram um mosaico de diferenças que são um dos mais valiosos patrimónios do nosso continente. Quando mencionamos essas mestiçagens falamos com algum receio como se o produto híbrido fosse qualquer coisa menos pura. Mas não existe pureza quando se fala da espécie humana. (COUTO, 2005:19)

Considerando que o imaginário africano sempre nos foi apresentado pela ótica do exotismo ${ }^{4}$ e que as literaturas que o assumem também foram recebidas pelo viés da diferença, só contemporaneamente tomamos ciência de que essa perspectiva pode se dar dentro do próprio universo interior do homem africano. A constante interferência imposta às populações, através de um contínuo assenhorear colonizador e a imposição de fronteiras geopolíticas - que desconsideraram culturas e identidades coletivas -, gerou um autodesconhecimento nesse homem nativo, dificultando uma percepção de si mesmo nas escritas inicialmente produzidas. Tais escritas foram, predominantemente, de caráter ideológico preconizando formulações libertárias.

Sob esse aspecto é necessária uma percepção dialética na leitura dos textos africanos, para que possamos compreender as novas linguagens e/ou os novos sentidos em construção,

$4 \mathrm{O}$ termo é utilizado, neste caso, no sentido de excêntrico e/ou extravagante, conforme a ideia predominante nos processos de colonização. 
ao que entendemos como um processo de travessia. Esse movimento ocorre por meio de diálogos com vozes periféricas, de desconstrução do olhar interno de exotismo e de uma ruptura na aceitação silenciosa das culturas exógenas. A literatura é, certamente, um espaço onde encontramos o que, num empréstimo a Laura Padilha (2002), designamos de "novos pactos, outras ficções", isto é, movimentos alternados de ruptura e ressurgimento, ou ainda, nas palavras da estudiosa, "um local onde vários saberes se entrecruzam", podendo produzir, como no caso de Mia Couto, "vários 'deslocamentos' diferentes numa mesma obra"5.

Situando em específico a literatura moçambicana, destacamos que é num momento de transição e/ou de travessia para um mundo pós-colonial que surge Mia Couto ${ }^{6}$, um escritor moçambicano - por opção pessoal - e um "cidadão do mundo" - por força da atividade. As fronteiras geográficas de sua cidadania permanecem na África, mas sua voz passou a traduzir outra - híbrida, no dizer de Homi Bhabha (2003) -, a dos sujeitos da margem, daqueles cuja inserção social na modernidade continua tão ilusória quanto foi a do período colonial. Maria Nazareth Fonseca e Maria Zilda Cury observam que, na produção literária do escritor moçambicano, surgem novas vozes enunciativas de um "entre-lugar", que articulam "espaços e culturas diversas" numa "“singularidade", ao mesmo tempo próxima e distante" (FONSECA e CURY, 2008:106. Grifo das autoras.). É o próprio escritor que esclarece sua posição:

O meu país tem países diversos dentro, profundamente dividido entre universos culturais e sociais variados. Sou moçambicano, filho de portugueses, vivi o sistema colonial, combati pela Independência, vivi mudanças radicais do socialismo ao capitalismo, da revolução à guerra civil. Nasci num tempo de charneira ${ }^{7}$, entre um mundo que nascia e outro que morria. Entre uma pátria que nunca houve e outra que ainda está nascendo. Essa condição de um ser de fronteira marcou-me para sempre. As duas partes de mim exigiam um médium, um tradutor. A poesia veio em meu socorro para criar essa ponte entre dois mundos distantes. (COUTO, 2005:106) ${ }^{8}$

De acordo com Fonseca e Cury (2208:16) situar-se como um ser de fronteira permite, ao autor, "abrigar as falas de outros espaços marginalizados do mundo", produzindo assim "uma escrita expandida". O exercício dessa escrita literária em Mia Couto se configura, desse modo, como um contínuo movimento de transposição, quer analisemos as oposições que ele coloca em diálogo, as revisitações que promove na configuração de seus narradores

\footnotetext{
5 Expressões utilizadas por Laura Cavalcante Padilha, na conferência de abertura do I Seminário Nacional "Quando foi o Pós-Colonial? Diálogos, perspectivas e limiares nas literaturas luso-africanas", realizado na UFRGS, em Porto Alegre, em 27 de junho de 2012.

6 Em 1983, Mia publica seu primeiro livro, Raiz de orvalho, "uma espécie de contestação contra o domínio absoluto da poesia militante, panfletária" como ele mesmo definiu. (COUTO, Mia apud CHABAL, Patrick. Vozes moçambicanas. Lisboa: Vega, 1994:286-287)

7 charneira $s . f$. 1. Juntura das valvas da concha. 2. Dobradiça. 3. Peça móvel com fuzilhão no centro da fivela. 4. Extremidade (de correia, cilha, etc.) que, dobrada e cosida, segura uma fivela. 5. Peça na ponta da chapa, onde joga o fradete da espingarda. 6. Fig. Pessoa ou coisa que une partes diferentes, que serve à união de dois grupos ou mundos diferentes; intermediário. charneira universal: aparelho que transmite o movimento de rotação de um a outro eixo. Dicionário Priberam da Língua Portuguesa. Disponível em: http://www.priberam.pt/dlpo/ dlpo.aspx. Acesso em: 30 abril 2013.

8 O trecho citado encontra-se em COUTO, 2005:106 e, também, em COUTO, 2009:123, ambos constantes em nossas referências. Na obra Pensatempos (2005), sob o título "O sertão brasileiro na savana moçambicana" (p. 103-112), integra o discurso de Mia Couto na Academia Brasileira de Letras, no Rio de Janeiro, em agosto de 2004. No livro E se Obama fosse africano? e outras interinvenções (2009), aparece sob o título "Encontros e Encantos - Guimarães Rosa (p.113-125), sendo parte de uma palestra do escritor na Universidade Federal de Minas Gerais, em 3 de julho de 2007, no ciclo de conferências "Sentimentos do mundo", promovido pela universidade em comemoração a seus 80 anos de fundação.
} 
e personagens, o tratamento que dá aos temas que percorre, quer consideremos o processo antropofágico que promove na Língua Portuguesa. Na perspectiva deste último processo, ele coloca que: "O dever do escritor para com a língua é recriá-la, salvando-a dos processos de banalização que o uso comum vai estabelecendo" (COUTO, 2005:111).

No Suplemento Cultural do Jornal do Fundão (Portugal, 26 de abril de 2012), em homenagem ao escritor moçambicano - pelo recebimento, em 2011, do Prêmio Eduardo Lourenço ${ }^{9}$-, Carmen Lúcia Tindó Secco, no artigo intitulado "Mia Couto: 'O outro das palavras e a busca do humano"" (SECCO, 2012:10), afirmou que: "nas obras de Mia Couto, o escrever se torna ato amoroso e afeta quem o lê. A linguagem é urdida com arte, consciência, criatividade. A imaginação se faz veículo de subversão e resistência". Na continuidade de suas palavras, destacamos ainda:

Mia Couto é um pensador múltiplo: das letras e da história; das tradições e da modernidade; da guerra e dos afetos; de Moçambique, da África e do mundo. Pensa o tempo e o humano, a vida e a morte. Poesia e humor se entrelaçam em sua escrita, cujo tom poético, por vezes, também irônico, não perde a acuidade reflexiva que põe em dúvida as "certezas científicas", com a arte de recriar palavras, colocando-as em estado de poesia. (SECCO, 2012:10. Grifos da autora.)

O "pensador” a que refere Carmen Lúcia Secco é o homem que ouve os homens ao seu redor e produz novos sentidos sobre o real vivido (no contexto de origem) e sobre o real imaginado. No exercício da escrita ele "fala" "com o/do/pelo" Outro e transpõe os limites geográficos e culturais "na" e "da" África, com novas linguagens, capazes de construir, conforme Fonseca e Cury (2008:107), "uma enunciação mais crítica, que não se furte a marcar posturas num mundo atravessado por intensas divisões". Dialogando com o pensador Edward Said (2005) $)^{10}$, as estudiosas afirmam, ainda, que "a condição do intelectual é a do exílio, a do 'fora-do-lugar', deslocando a frente da cena. Essa representação do intelectual, a quem se atribui um papel político na cena pública, mostra a atualidade da literatura de Mia Couto, atenta a questões tão candentes no mundo contemporâneo e com a posição da literatura neste contexto" (FONSECA, CURY, 2008:106. Grifo das autoras.).

A capacidade de mediação entre a herança cultural e a influência externa é o que Mia Couto costuma referir como a tradução efetivada pelo escritor. Em dezembro de 2003, em Maputo, Moçambique, em entrevista a Vera Maquêa ${ }^{11}$, ele faz menção a essa intermediação pela palavra escrita:

A chamada "identidade moçambicana" só existe na sua própria construção. Ela nasce de entrosamento, de trocas e destrocas. No caso da literatura é o cruzamento entre a escrita e a oralidade. Mas para ganhar existência na atualidade, no terreno da

9 O Prémio Eduardo Lourenço é atribuído anualmente pela Comunidade de Estudos Ibéricos (CEI), presidida pelo Reitor da Universidade de Coimbra, pelo Reitor da Universidade de Coimbra e pelo Presidente da Câmara Municipal da Guarda, tendo Eduardo Lourenço como Director Honorífico. A premiação foi instituída em 2004, com o propósito de "galardoar personalidades ou instituições de língua portuguesa ou espanhola que tenham sido protagonistas de uma intervenção relevante e inovadora no âmbito da cooperação e no domínio das identidades, das culturas e das comunidades ibéricas". Disponível em: http://www.cei.pt/eduardolourenco/ premio el arquivo.htm. Acesso em: 28 abril 2013.

10 Fonseca e Cury utilizam como referência a edição brasileira da Companhia das Letras, publicada em 2005. 11 A entrevista encontra-se publicada como Capítulo 5, p. 191-210, intitulado "Diálogos literários" na obra constante em nossas referências como MACÊDO, Tania; MAQUÊA, Vera. Literaturas de lingua portuguesa: marcos e marcas - Moçambique. São Paulo: Artes e Ciência, 2007. 
modernidade, Moçambique deve caminhar pela via da escrita. Entramos no mundo pela porta da escrita, de uma escrita contaminada (ou melhor fertilizada) pela oralidade. Não podemos ir pela porta de trás, pela via do exótico terceiro-mundista. O fato é que há uma espécie de costura que necessita ser feita [...]. São costuras que atravessam o tempo, e que, quase sempre, implicam uma viagem através da escrita. No fundo, o meu próprio trabalho literário é um bocadinho esse resgate daquilo que se pode perder, não porque seja frágil mas porque é desvalorizado num mundo de trocas culturais que se processam de forma desigual. Temos aqui um país que está a viver basicamente na oralidade. Noventa por cento existem na oralidade, moram na oralidade, pensam e amam nesse universo. Aí eu funciono muito como tradutor. Tradutor não de línguas, mas desses universos... (MACÊDO e MAQUÊA, 2007:195196. Grifo das autoras).

Ao postular uma posição de mediação cultural, através do seu texto literário, o escritor assume a sua participação como testemunha e como ator do processo de construção social e cultural do seu país. Pensar Moçambique através do tempo e criar espaços de narrativa da nação são as funções delegadas aos narradores e personagens miacoutianos, quer tenhamos como leitura o primeiro romance do autor, Terra sonâmbula ${ }^{12}$ de 1992 ou $O$ outro pé da sereia ${ }^{13}$, publicado em 2006. Acompanhamos Fonseca e Cury quando identificam, no primeiro, a palavra escrita "como um local privilegiado de conservação e reinvenção da memória" (2008:25). Terra sonâmbula se fragmenta, aparentemente, em duas narrativas paralelas: a atual, em terceira pessoa, que situa o tempo presente de guerra e destruição onde encontramos, na terra devastada, o jovem Muidinga e o velho Tuahir; a segunda, narrada em primeira pessoa por Kindzu, traz o tempo passado dos registros da memória e do sonho (o mar como rumo em busca de uma nova terra) em cadernos encontrados no presente dentro de uma mala. Essa "viagem" literária de Mia Couto revela um outro olhar que sobrepõe as duas temporalidades, suas personagens e suas histórias, como analisam Tania Macêdo e Vera Maquêa (2007):

A ilusão de que essas seriam duas histórias marcadas em distintas temporalidades não se demora a revelar-se. Ambas vão imbricando-se nas personagens, espaços e tempos uma da outra de tal maneira que o romance se torna um jogo de perspectiva. Os narradores já não têm histórias individuais para contar a não ser a história que os enreda a todos na mesma malha de miséria e sofrimento bordada com as sombras da morte que ronda a todos naquele lugar. (MACÊDO e MAQUÊA, 2007:60-61)

A superação e o recomeço através da (re)escrita findam esse primeiro romance, quando "então as letras, uma por uma, se vão convertendo em grãos de areia e, aos poucos todos os meus escritos [Kindzu] se vão transformando em páginas de terra" (COUTO, 2007:204). É a palavra que mantém a memória e supera o tempo, transpõe a dor da guerra e vivifica a "capacidade de sonhar" como reforça Pires Laranjeira (1993) ${ }^{14}$, num texto

12 O romance Terra sonâmbula foi publicado inicialmente pela Editorial Caminho, de Lisboa, em 1992 e recebeu o Prémio Nacional de Ficção da Associação dos Escritores Moçambicanos em 1995, sendo considerado por um júri na Feira Internacional do Zimbabwe um dos doze melhores livros africanos do século XX. A primeira edição brasileira ocorreu em 2007, pela Companhia das Letras.

13 O outro pé da sereia foi publicado em 2006, simultaneamente, pela Editorial Caminho, de Lisboa, e pela Companhia das Letras, de São Paulo. Em 2007, o romance recebeu o $5^{\circ}$ Prêmio Passo Fundo Zaffari \& Bourbon



14 Laranjeira, Pires. Mia Couto: Sonhador de lembranças, inventor de verdades. Letras \& Letras, n. 100, Set, 1993. In: Cavacas, 2000:15-16. 
sobre a obra intitulado "Mia Couto: Sonhador de lembranças, inventor de verdades". É a linguagem lírica que preenche os signos de recomeço e de (re)invenção do futuro possível para a nação, pois os tempos se tornam confluentes e a palavra, que contém o passado, se converte em uma possibilidade de futuro, em uma nova terra.

Cabe a $O$ outro pé da sereia revisitar também os papéis com a escrita do passado, com o registro das letras que vão se apagando dentro de um baú enterrado desde a fase histórica da conquista das terras moçambicanas. Novamente duas aparentes narrativas paralelas se imbricam no ato de leitura no presente, quando a personagem Mwadia lê para a mãe, no ano de 2002, o diário de viagem de 1560 , e ambas se acumpliciam no resgate do passado (coletivo e individual) e se libertam da modernidade opressora encontrando, desse modo, o seu próprio caminho junto ao rio, espaço onde as duas temporalidades se conectam. Transcorrem, assim, duas histórias paralelas que, assim como em Terra sonâmbula, alternam-se nos capítulos do romance e acabam por fundir-se num destino cumprido pelos relatos ancestrais. A modernidade de Moçambique se perfila no entrecruzamento de personagens e no contato que estes estabelecem entre as duas épocas, tanto pela ordem do religioso (viés pelo qual a diegese d'O outro pé da sereia se efetiva), quanto pela (re) visitação e (re)elaboração de uma tradição que preenche o signo do exótico conforme a modernidade pressupõe. A errância, a viagem, o preenchimento de signos vazios, o deslocamento geográfico de símbolos e o contato contrastivo de cultos e crenças, são tematizados na escrita que abarca a oralidade e resignifica a História passada.

As duas obras circulam por espaços de memórias coletivas e transitam por tempos inconclusos, abertos à revisitação que somente a ficção pode promover. Os dois romances concretizam, na ficção, os movimentos que Homi Bhabha (2003) propõe como "além" e que são vivenciados nos tempos que discutimos como situações de "pós":

Inícios e fins podem ser os mitos de sustentação dos anos no meio do século, mas, neste fin de siècle, encontramo-nos no momento de trânsito em que o espaço e tempo se cruzam para produzir figuras complexas de diferença e identidade, passado e presente, interior e exterior, inclusão e exclusão. (BHABHA, 2003:19)

Ainda mencionando o Jornal do Fundão, encontramos, no artigo "Mia Couto, assaltante de fronteiras", assinado pela escritora portuguesa Lídia Jorge, uma assertiva com a qual nos identificamos. Diz ela: "gosto do Mia, gosto do que escreve e ainda por cima, gosto do que pensa" (JORGE, 2012:8). O pensar, citado por ela, remete-nos aos textos não literários, às crônicas jornalísticas, às colaborações em revistas, às entrevistas e às palestras que ele profere nos mais diferentes eventos e lugares. São manifestações de um cidadão, de um homem de seu tempo, que assume posições político-ideológicas e opina sobre o que vivencia e/ou assiste, que discute temas afins ao exercício da escrita literária e da biologia - outro universo em que atua -, que questiona e reflete sobre as certezas e incertezas de que é testemunha. Sintetizando, é um homem de falar, escrever e pensar, uma tríade que o coloca, ultrapassando suas intrínsecas fronteiras, diante do Outro.

Em julho de 2004, num texto elaborado para crianças de um programa interescolar ${ }^{15}$, Mia Couto faz referência à integração entre as duas atividades que exerce, a de biólogo e de escritor, pelo fato de ambas serem "vizinhas e complementares" (COUTO, 2005:45) por

15 Texto elaborado para crianças lusófonas integradas no programa interescolar "Ciência Viva", publicado sob o título "Uma palavra de conselho e um conselho sem palavras" em COUTO, Mia. Pensatempos. Textos de opinião. Lisboa: Caminho, 2005, p. 45-49. 


\section{Conexão Letras}

ultrapassarem limites, uma na busca do conhecimento e a outra da "capacidade de sentir" (COUTO, 2005:45). Esse constante direcionamento para a faculdade de ir além do que está posto, de recusar fronteiras, é uma das características, na obra miacoutiana, que a insere no universo de formulações sob o viés do "pós". As discussões conceituais presentes na contemporaneidade ampliam as possibilidades de diálogos entre as literaturas africanas de modo geral e a cultura ${ }^{16}$ ocidental, colocando em discussão não somente questões historiográficas e/ou históricas, mas destacando a relação entre o modo como o Ocidente recebe essas produções e a visão que tais literaturas têm de si mesmas. Nessa linha de raciocínio, destacamos trechos de uma conferência do escritor, em Estocolmo, em junho de $2008^{17}$ :

Sou biólogo e viajo muito pela savana do meu país. Nessas regiões encontro gente que não sabe ler livros. Mas que sabe ler o seu mundo. Nesse universo de outros saberes, sou eu o analfabeto. Não sei ler sinais da terra, das árvores e dos bichos. Não sei ler nuvens, nem o prenúncio das chuvas. [...] Nessas visitas que faço à savana, vou aprendendo sensibilidades que me ajudam a sair de mim e a afastar-me das minhas certezas. [...]

[...] Há trinta anos, quase nenhum moçambicano tinha o português como língua materna. Agora, mais de 12 por cento dos moçambicanos têm o português como seu primeiro idioma. E a grande maioria entende e fala português inculcando na norma portuguesa as marcas das culturas de raiz africana.

Esta tendência de mudança coloca em confronto mundos que não são apenas linguisticamente distintos. Os idiomas existem enquanto parte de universos culturais mais vastos. Há quem lute para manter vivos os idiomas que estão em risco de extinção. Essa luta é absolutamente meritória e recorda a nossa batalha como biólogos para salvar do desaparecimento espécies de animais e plantas. Mas as línguas salvam-se se a cultura em que se inserem se mantiver dinâmica. Do mesmo modo, as espécies biológicas apenas se salvam se os seus habitats e os processos naturais forem preservados.

As culturas sobrevivem enquanto se mantiverem produtivas, enquanto forem sujeito de mudança e elas próprias dialogarem e se mestiçarem com outras culturas. As línguas e as culturas fazem como as criaturas: trocam genes e inventam simbioses como resposta aos desafios do tempo e do ambiente. (COUTO, 2009:17-18)

Nas diversas facetas desse autor, reconhecemos o seu particularizado instrumento de comunicação e de criação, a Língua Portuguesa, comum a todos nós, que é nossa (na perspectiva miacoutiana), e que pode unir ou separar, de acordo com o tempo, a geografia ou a intenção. Está na gênese dos debates sobre pós-colonialismo o diálogo e a reflexão dentro do contexto cultural da língua e Mia Couto é um autor que representa tais posturas ao tomar a si o seu idioma oficial para dele abstrair o essencial, creditando-lhe outros significados provindos de múltiplas origens do mosaico cultural moçambicano. É essa sua aptidão para refletir e dialogar que Lídia Jorge (2012) identifica no escritor:

Na prática, Mia Couto cumpre aquilo que foi uma das definições de Kafka sobre o poder da Literatura, um assalto contra todas as fronteiras. Mia assalta as fronteiras de Moçambique falando da sua terra abensonhada, assalta-as fazendo viajar a sua

16 Utilizamos aqui o termo "cultura" no sentido de um complexo de fatores que inclui a crítica especializada, a indústria editorial, os interesses midiáticos, econômicos, políticos e/ou ideológicos, entre outros.

17 Palestra de Mia Couto, em Estocolmo, em junho de 2008, na Conferência Internacional de Literatura WALTIC, intitulada "Línguas que não sabemos que sabíamos" que está publicada em: COUTO, Mia. E se Obama fosse africano? e outras interinvenções. 2. ed. Lisboa: Caminho, 2009, p. 24-25. 
narrativa de vida, transformada num poderoso passaporte, entre África, a Europa e o resto do mundo, usando para isso a sua língua de berço, a Língua Portuguesa. Melhor dizendo, transpondo as fronteiras da Língua Portuguesa, usando-a como entende, criando dentro dela uma língua própria, reconhecível como sua, mas uma língua pessoal que a todos serve, e a muitos ensina que uma das formas de ser livre consiste em inventarmos novas formas de dizer. (JORGE, 2012:8)

A Língua Portuguesa é assumida por Mia Couto como sua, enquanto cidadão educado no idioma luso, e nessa apropriação, ele a reveste culturalmente com os sotaques que o cercam os quais fazem parte, de modo igual, do seu processo de construção de cidadania. Tendo como ponto de partida o escritor angolano Luandino Vieira ${ }^{18}$, com seu português literário repleto de sotaque dos musseques ${ }^{19}$, e, com a descoberta do brasileiro Guimarães Rosa, de acento sertanejo, o moçambicano Mia Couto retoma a linguagem do colonizador, comum a todos, e endossa nela o ritmo da oralidade do seu contexto e a poesia de sua vocação. Comum aos três escritores, temos a literatura que se embasa na diferença e na expressão de si mesmo através da língua do Outro, e, se há uma herança comum, ela também é diversa, como foram os processos sociais que vivenciaram. A esse processo Maria Nazareth Fonseca designou como um alocar de línguas "em outras feições, nas quais elas se mostram as mesmas e diferentes ao mesmo tempo" (FONSECA, 2008:183. Grifos da autora.), enquanto ocorrências que ultrapassam a geografia africana, atendo-se a outros decursos colonialistas. Sobre essa inter-relação entre o "mesmo" e o "diferente", na escrita miacoutiana, a estudiosa especifica:

Esse processamento de misturas linguageiras, que Mia Couto bebe em Luandino Vieira, antes do contato com Guimarães Rosa, aproxima-o de outros escritores transgressores, comparsas na arte de subverter normas e leis da escrita literária, de aventurar-se pelo risco de produzir literatura percorrendo "passagens do limite"20, que propiciam a utilização da língua herdada da colonização sempre tensionada, com sintaxe, léxico e campos semânticos sempre em convulsão.

A obra literária de Mia Couto é escrita em português, mas os ruídos que dela brotam deslocam a língua européia, alocam construções que a subvertem e estimulam uma transgressão escancarada. (FONSECA, 2008:87-88. Grifos da autora.)

18 A exemplaridade de Luandino Vieira e Guimarães Rosa é reiterada por Mia Couto em inúmeras palestras e entrevistas. Nas presentes considerações, utilizamos como referências: COUTO, 2005; COUTO, 2009; MACÊDO e MAQUÊA, 2007.

19 "A palavra musseque tem origem no kimbundo (mu seke) e significa areia vermelha. A um dado momento, musseque, passa a designar os grupos de palhotas, que se adensam no alto das barrocas e que por semelhança à SEKE (vermelho ocre) toma o nome do material (areia) sobre o qual se implantam. A partir de 1962, a febre da construção civil e o lançamento da indústria, fascina cada vez mais as populações rurais que abandonam os seus locais de origem e migram para a cidade grande, Luanda. Estas gentes instalam-se nos musseques e reagrupam-se segundo as suas origens. Os musseques passam a designar o espaço social dos colonizados, assalariados, reduto da mão de obra barata e de reserva, ao crescimento colonial, colocados à margem do processo urbano, surgindo como espaço dos marginalizados, e cuja fisionomia está em constante transformação. $\mathrm{O}$ aspecto construtivo diferenciado surge de acordo com a origem dos seus habitantes, a sua ocupação e o grau de adaptação à cidade; existe sempre um traço comum - a organização do espaço. $\mathrm{O}$ musseque é fechado sobre si mesmo, num entrelaçado complexo e orgânico de ruelas, "pracetas" e corredores." Disponível em: http:// arkivao.blogspot.com.br/2006/07/musseques-de-luanda.html Acesso em: 9 de abril de 2013.

20 Cf. NR original: "Utilizamos a expressão 'passage de la limite', usada por Jacques Derrida (1996, p. 59) [DERRIDA, Jacques. Le monolinguisme de l'autre. Paris: Éditions Galilée, 1996] para caracterizar a escritura como uma apropriação 'apaixonada e desesperada' da língua, através de um trabalho que, ao mesmo tempo, deforma, reforma e transforma". 
Ao tomar a si a língua herdada e nela inscrever os "ruídos" nativos provindos dos mais diversos espaços onde outras línguas são dominantes, Mia Couto traz ao texto não só o rompimento com a fala do colonizador, mas a cisão da forma como esta havia permanecido na sociedade moçambicana. A sua posição de tradução não de um idioma, mas de uma cultura, implica numa relação antropofágica com a palavra que assume como sua e com a qual constrói novos sentidos na sua escrita literária. Surge dessa alteridade a diferença que lhe permite criar novos sentidos, literal ou metaforicamente, para falar com os sotaques da sua terra abensonhada, como referiu Lídia Jorge (2012). Ao usarmos o termo "falar" aglutinamos a escrita literária e a escrita oralizada, ou, na acepção de Terezinha Taborda Moreira (2005), considerando a presença da oralitura na produção miacoutiana. Essa é a formulação da "escrita transgressora" citada por Maria Nazareth Fonseca (2008:87) que Mia Couto exercita ao longo de sua obra, tanto pela posição de ultrapassar as regras linguísticas do idioma, quanto pela criação vocabular que promove ao unir significados e cooptar na prosa sua expressão poética.

É nessa “mistura linguageira", referida por Fonseca (2008:87), que ele assume a influência de Luandino Vieira e Guimarães Rosa, de acordo com suas próprias palavras, em dois trechos da entrevista para Vera Maquêa:

Foi por sugestão de Luandino que eu conheci a escrita de Guimarães Rosa. Nos anos oitenta, estávamos em guerra, em pleno isolamento do mundo. Eu nem sabia da existência do Guimarães Rosa. [...] Quando nos anos 70, descobri Luandino isso foi uma revelação importante, decisiva mesmo. Escrevo o primeiro livro de contos ${ }^{21}$ muito influenciado... eu não tenho medo da palavra "influenciado". Fui marcado por esse encontro com o escritor angolano e desse encontro surgiriam caminhos que eu pensava quase interditos. Durante anos mantive essa relação com os livros do Luandino e lia tudo que eu podia desse autor. E li numa entrevista que ele deu, que ele próprio se declara influenciado pelo Guimarães Rosa. Fiquei curioso. Afinal, a relação que ele confessava manter com Guimarães Rosa era semelhante àquela que eu estava mantendo com o texto dele. A minha procura dos livros de Rosa começou então. Mas não havia hipótese: nós não tínhamos livrarias, não mantínhamos relacionamentos próximos com o exterior. Eu devia esperar que alguém viesse do Brasil e me trouxesse um livro. Demorou muito tempo, um dia eu recebo as Primeiras estórias $^{22} \ldots$ Estas estórias ${ }^{23}$, só li posteriormente. Eu recebo as Primeiras estórias e realmente eu entendi bem: estava ali alguém que tinha conseguido fazer na língua portuguesa um processo de reencantamento profundo por via da emergência da poesia... (MACÊDO e MAQUÊA, 2007:201-202. Grifo das autoras.)

Eu sou surpreendido por Guimarães Rosa já depois do primeiro livro de contos ter sido publicado... eu já tinha escrito esse primeiro livro de contos e nesse livro (que se chama Vozes anoitecidas) eu já tinha iniciado um percurso de transgressão linguística, aquilo que se entende como reinvenção da palavra e recriação da língua. [...] entre o primeiro livro de contos e o segundo livro de contos que é Cada homem é uma raça ${ }^{24}$, tu vês a chegada do Guimarães Rosa. E é visível que eu conversei com esta

21 O livro é Vozes anoitecidas, publicado inicialmente em 1986, em Maputo, Moçambique, pela Associação dos Escritores Moçambicanos (AEMO), como parte da Colecção Karingana, com 114 páginas. No ano seguinte, foi publicada a primeira edição portuguesa (151 páginas), pela Editorial Caminho de Lisboa, com um prefácio do poeta moçambicano José Craveirinha.

22 O livro Primeiras estórias, de Guimarães Rosa, foi publicado, inicialmente, em 1962, no Rio de Janeiro pela José Olympio, reunindo 21 contos.

23A obra Estas estórias, de Guimarães Rosa, foi publicada, postumamente, em 1969, no Rio de Janeiro, pela José Olympio, reunindo contos que tematizam o grande sertão.

24 Cada homem é uma raça foi publicado em Lisboa, pela Caminho, em 1990, como parte da Colecção Uma Terra sem Amos, n. 44. 
outra pessoa, com este espírito de quem não morreu mas ficou encantado. Ele me abriu campos no sentido de que me autorizou desenvolver o meu próprio caminho. (MACÊDO e MAQUÊA, 2007:203.

Ao assumir uma interação entre literatura moçambicana, angolana e brasileira, o escritor deixa aberto o processo de constante diálogo entre a herança cultural portuguesa absorvida por essas sociedades, do qual podem emergir tantas escritas quantas forem as suas particulares evoluções. Se considerarmos temáticas ou regras ortográficas, encontraremos um movimento particular de nacionalização em cada cultura e novas perspectivas sobre a execução desses movimentos, nos seus múltiplos escritores. Em Mia Couto, constatamos uma particular articulação entre a poesia e a prosa, estabelecida através de nexos temáticos e linguísticos. A transgressão miacoutiana se dá, fundamentalmente, pelo uso da palavra, como ele mesmo descreve: "Eu já bebia na poesia um gosto pela desobediência da regra, mas foi com o autor da Terceira Margem do Rio $^{25}$ que eu experimentei o gosto pelo namoro entre língua e pensamento, o gosto do poder divino da palavra" (COUTO, 2009:115).

A inserção da poesia na prosa não é exclusiva da literatura miacoutiana, mas reitera a postura do autor em relação ao ato de criar tessituras que reflitam o sentimento interior nos relatos da exterioridade. Sentir-se liberado para estabelecer seus próprios nexos e ultrapassar as barreiras do convencional, os "caminhos interditos", é o que decorre do contato do escritor moçambicano com os textos do angolano Luandino e do brasileiro Guimarães. Assim, é pelo viés da diferença que se estabelece a semelhança. Se atentarmos que Luandino escreveu num período de encarceramento pela $\operatorname{PIDE}^{26}$ e deu voz aos habitantes dos musseques de Luanda, e que Guimarães, a partir da sociedade urbana, deu espaço ao homem rural, teremos um importante ponto de contato entre as três produções literárias, as quais trazem ao texto a vivência e o imaginário dos seres da margem. Na entrevista a Vera Maquêa (2007:205), Mia Couto discorre sobre a linguagem literária que o encanta e na qual busca situar a sua escrita referindo-se a uma língua "em trânsito e em transe". Nas suas palavras, o escritor "surge como que desamparado de sua própria língua materna, como se perdesse a memória e tivesse que inventar a sua própria casa" (MACEDO e MAQUÊA, 2007:204). Ao ser perguntado se isso levaria a uma "língua em trânsito", ele responde que é uma língua não só "em trânsito", mas também "em transe", explicando:

Só num estado de transe se é capaz de ouvir outro ser, só nesse estado de enlevo nos retiramos da página. O que me acontece quando leio Rosa, Adélia $\operatorname{Prado}^{27} \ldots$ para mim ela é outro mestre, quando eu chamo de mestre é porque são textos que me roubam que seria o verbo "ler". O que se sente é o seguinte: eu não os posso ler, compreendes? É uma confissão que raramente faço, mas eu adoro livros que eu não

25 Conto da obra Primeiras estórias, de Guimarães Rosa, que abrange uma textualidade claramente reconhecível tanto no segundo livro de contos de Mia Couto (Cada homem é uma raça), como em suas obras subsequentes. Referimo-nos a imbricação de diferentes tempos narrativos (cronológico e psicológico), a presença de personagens sem nome - identificados pelos seus papéis e funções sociais -, a recriação sintática e o diálogo com a oralidade e, destacadamente, o fundamento do rio como metáfora temática e espaço da narração. $\mathrm{O}$ próprio título da estória remete a uma possibilidade de leitura que ultrapassa a narrativa, instaurando uma terceira margem, ou, como costuma afirmar o escritor moçambicano, abre à possibilidade de sonhar.

26 Polícia Internacional e de Defesa do Estado (PIDE): polícia portuguesa existente entre 1945 e 1969, cuja atuação se deu tanto na metrópole quanto nas colônias. Luandino Vieira foi preso em 1959 e condenado, em 1961, a uma pena de 14 anos que cumpriu no Campo do Tafarral, em Cabo Verde.

27 Conforme Mia Couto, Adélia Prado, Clarice Lispector, Rubem Fonseca, Raquel de Queiroz, Jorge Amado, Graciliano Ramos, José Lins do Rego e os poetas Manuel Bandeira e Manoel de Barros, são escritores que exerceram uma influência determinante, em Moçambique, nas décadas de 1950 e 1960 (MACÊDO e MAQUÊA, 2007:199). 
consigo ler desse ponto de vista de que aquilo que estou a fazer não é ler, é uma outra coisa, tem que se inventar um verbo para isso. Porque acontece quando estou a ler o Guimarães Rosa ou a Adélia Prado, certos textos me atiram para fora da página, eu tenho que parar porque eu começo escutando vozes que disputam o que está fora do registro gráfico, está para além da página. Eu entro em transe, em trânsito, nesse sentido. (MACÊDO e MAQUÊA, 2007:205)

O estado de transe reportado por Mia Couto corresponde a uma assertiva sua, em 2002, na cidade do Cabo, África do Sul, na cerimônia de entrega do "Prêmio Internacional dos 12 Melhores Romances de África", quando afirmou que um escritor é alguém que "produz pensamentos", que "é capaz de engravidar os outros de sentimento e encantamento" (COUTO, 2005:63), isto é, conduzir o outro, no caso, o leitor, a uma viagem "no" e "além" do texto. Essa relação equivale à ideia presente em "A terceira margem do rio" e corresponde às explicitações de Mia Couto, na mesma ocasião, de que o escritor desafia os limites do que é visto como politicamente correto e subverte os próprios critérios dessa posição questionando, desse modo, os limites da razão.

Subverter, encantar, ultrapassar e inventar estão entre os verbos conjugados na criação literária miacoutiana e trazem ao ato de elaboração textual múltiplas possibilidades de significação da palavra, preenchimentos de sentidos que podem advir do passado, da imaginação ou do questionamento do porvir. A poeticidade presente na prosa e a liberdade de romper fronteiras são marcas identificáveis na obra de Mia Couto, que tanto podem ser vistas como originais, como podem ser associadas a um contexto de criação do que costumamos designar como pós-colonial, em relação à literatura dos países de colonização portuguesa. Essa perspectiva corresponde ao que Inocência Mata designou como "nova geografia linguística póscolonial" em seu artigo "Mia Couto, poeta de iluminação ensaística", no Jornal do Fundão (2012:14).

No prefácio da edição moçambicana de Vozes Anoitecidas, de 1986, Luís Carlos Patraquim alude a uma "descolonização da palavra" (COUTO, 2006:16) para situar a autenticidade da produção, ressaltando que ali se presenciava a obra do poeta marcando uma nova prosa. No ano seguinte, na edição portuguesa, é José Craveirinha quem prefacia, afirmando que nos "magníficos slides" do gênero conto se "mantém - e com sensibilidade o bom poeta que no género poesia já provara ser" (COUTO, 2006:11). Os três intelectuais, distanciados por mais de duas décadas, corroboram o que chamamos "novas tessituras", isto é, uma escrita que reúne características literárias reconhecidas e novas formulações, originando uma obra de nova e vigorosa matriz identitária.

\section{Referências}

BHABHA, Homi K. O local da cultura. Tradução de Myriam Ávila, Eliana Lourenço de Lima Reis e Gláucia Renate Gonçalves. Belo Horizonte: UFMG, 2003.

CAVACAS, Fernanda. Mia Couto: pensatempos e improvérbios. Lisboa: Mar Além; Instituto Camões, 2000, Coleç̧ão Mar Profundo, n. 2.

COUTO, Mia. Cada homem é uma raça. Rio de Janeiro: Nova Fronteira, 1998.

E se Obama fosse africano? e outras interinvenções. 2. ed. Lisboa: Caminho, 2009.

O outro pé da sereia. São Paulo: Companhia das Letras, 2006.

Pensatempos. Textos de opinião. 2. ed. Lisboa: Caminho, 2005.

Terra sonâmbula. Lisboa: Caminho, 1995. 
Vozes anoitecidas. 8. ed. Lisboa: Caminho, 2006.

FONSECA, Maria Nazareth Soares. Literaturas africanas de língua portuguesa: percursos da memória e outros trânsitos. Belo Horizonte: Veredas \& Cenários, 2008.

; CURY, Maria Zilda Ferreira. Mia Couto: espaços ficcionais. Belo Horizonte:

Autêntica, 2008.

JORGE, Lídia. "Mia Couto, assaltante de fronteiras". Jornal do Fundão. Fundão [Portugal], 26 abr. 2012. Suplemento VIII [p. 8].

LEITE, Ana Mafalda. Literaturas africanas e formulações pós-coloniais. Lisboa:

Colibri, 2003.

. Oralidades \& escrituras nas literaturas africanas. Lisboa: Colibri, 1998.

MACEDO, Tânia; MAQUEAA, Vera. Literaturas de língua portuguesa: marcos e marcas - Moçambique. São Paulo: Artes e Ciência, 2007.

MATA, Inocência. "Mia Couto, poeta de iluminação ensaística". Jornal do Fundão. Fundão [Portugal], 26 abr. 2012. Suplemento XIV [p. 14].

MOREIRA, Terezinha Taborda. O vão da voz: a metamorfose do narrador na ficção moçambicana. Belo Horizonte: PUCMinas, 2005.

PADILHA, Laura Cavalcante. Novos pactos, outras ficções: ensaios sobre literaturas afro-luso-brasileiras. Porto Alegre: EDIPUCRS, 2002.

ROSA, João Guimarães. Pequenas estórias. 14. ed. Rio de Janeiro : Nova Fronteira, 1985.

SAID, Edward. Representações do intelectual: conferências Reith de 1993. Porto: Colibri, 2000.

SECCO, Carmen Lucia Tindó. "Mia Couto: 'O outro lado das palavras e a busca do humano"”. Jornal do Fundão. Fundão [Portugal], 26 abr. 2012. Suplemento X [p. 10]. VIEIRA, José Luandino. Luuanda. São Paulo: Ática, 1982. 